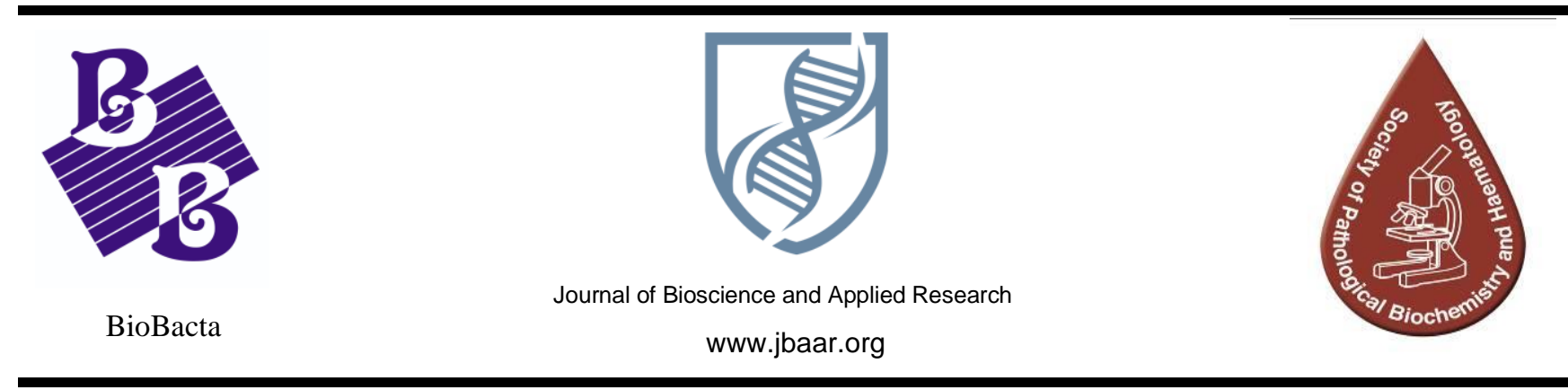

\title{
Bio-Remediation of Pb-contaminated Soil Cultivated With Faba Bean Via Application of Rhizobacteria Bacillus amyloliquefaciens subsp. plantarum UCMB 5033
}

\author{
Rania Mohammed Sabri Sultan ${ }^{1}$, Raad Homod Mohammed Al-Hazmi ${ }^{2}$ \\ ${ }^{1}$ Department of Biological Sciences, Faculty of Science, King Abdulaziz University Jeddah, 21589, Saudi Arabia \\ ${ }^{2}$ Ministry of Education, Western Region, Jeddah, Saudi Arabia
}

DOI: 10.21608/jbaar.2020.122917

\begin{abstract}
Bio-remediation of Faba bean (Vicia faba cv. luz deotono) plants growing under lead $(\mathrm{Pb})$ contaminated soil using the bacteria strain Bacillus amyloliquefaciens subsp. plantarum UCMB 5033 was tested under three $\mathrm{Pb}$ concentrations $(2000 \mathrm{mg} / \mathrm{L} 0.5 \%, 2500 \mathrm{mg} / \mathrm{L} 1.0 \%, 3000 \mathrm{mg} / \mathrm{L} 5 \%)$. Growth parameters (plant height, plant fresh weight, and plant dry weight of the Pb-treated bacteria inoculated Faba bean plants showed significant increases compared to the $\mathrm{Pb}$-treated non-inoculated Faba bean plants under $\mathrm{Pb}$ concentration of $0.5 \%$ and $1.0 \%$ giving $5.76 \%, 50.43 \%$ increases in height, $42.68 \%, 253.36 \%$ increase in fresh wt., and $237.69 \%, 325.97 \%$ increase in dry wt. Regarding the plant nutrient, NPK contents the noninoculated $\mathrm{Pb}$-treated plants gave significantly the highest $\mathrm{N}$ content under all $\mathrm{Pb}$ concentration levels and the highest $\mathrm{PK}$ contents under $\mathrm{Pb}$ concentrations 0.5 and $1.0 \%$ compared to the bio-remediated plants. But the bio-remediated plants dominated the non-inoculated Faba bean plants in absorbing the highest PK contents under a $\mathrm{Pb}$ concentration of 5.0\%. Regarding $\mathrm{Pb}$ absorption, the bio-remediated plants dominated the non-inoculated Faba bean plants and absorbed the highest $\mathrm{Pb}$ especially under $1.0 \% \mathrm{~Pb}$ concentration. Bacillus amyloliquefaciens subsp. plantarum UCMB 5033 may be considered a bio-remediator for Faba bean plants grown under $\mathrm{Pb}$ contaminated soils.
\end{abstract}

Keywords: Bioremediation, $\mathrm{Pb}$ resistance bacteria, Faba beans

Received: August 23, 2020. Accepted: November 10, 2020. Published: November 12, 2020 


\section{INTRODUCTION}

Some lead-resistant bacteria have been found to play a specific role in the growth of lead-exposed plants. For example, the endophyte Bacillus $s p$. MN3-4 increases $\mathrm{Pb}(\mathrm{II})$ accumulation in Alnus firma, and Pseudomonas fluorescens $G 10$ and Mycobacterium sp. G16 promotes plant growth and reduces $\mathrm{Pb}$ toxicity in Brassica napus (Sheng et al., 2008; Shin et al., 2012). Additionally, the activity of the lead-resistant bacteria Streptomyces sp. and Ps. Vesicularis has been noticed on the marble facade of a cathedral, where it was manifested in the form of red stains. These bacteria were capable of producing a red and red-brown pigment, identified as the lead tetroxide, minium (red lead, Pb3O4)(Zanardiniet al., 1997). Some heavy metals have biological roles and are detrimental to the organisms even at very low concentrations (cadmium, lead, mercury) (Rathnayake et al., 2010). The major threat that heavy metals pose is that they persist in the environment, accumulate in the biota, and thereby enter the food chain causing health problems to higher animals and humans (Zhang et al., 2009). Chen and Wang, (2007), Sun and Shao, (2007) isolated several micro-organisms resistant to lead $(\mathrm{Pb})$ among them is the grampositive bacteria Bacillus cereus, Arthrobacter sp., and Corynebacterium sp. And the gram-negative bacteria Pseudomonas marginalis, P. vesicularis and Enterobacter sp., and fungi Saccharomyces cereviside and Penicillium sp. Six bacterial strains were found to be most resistant isolates and amongst them, one isolate showed maximum resistance to lead which was identified as Bacillus cereus, Scanning electron microscopic (SEM) photographs and Energy-dispersive X-ray spectroscopy (EDS) signature of Bacillus cereus revealed that lead was adsorbed to the cell surface, confirming biosorption capacity of the bacteria (Murthy et al. 2012). This study aims to examine the effect of the bacteria Bacillus amyloliquefaciens subsp. plantarum UCMB 5033 as a bio-remediator to Faba bean plants growing in $\mathrm{Pb}$ contaminated soils.

\section{MATERIALS AND METHODS}

\section{The pot experiments}

Bacillus amyloliquefaciens subsp. plantarum UCMB 5033, isolated from a lead concentration of i.e., $2500 \mathrm{mg} / \mathrm{l} \mathrm{PbCl}_{2}$ (lead chloride) was selected for evaluating its abilities in absorbing lead in the liquid medium. A pot experiment was carried out in the greenhouse of the biological science department, faculty of science, King Abdul-Aziz University to study the bioremediation process of $\mathrm{Pb}$ in sandy soil cultivated with faba bean. Plastic pots of $25 \mathrm{ml}$ diameter were filled with $8 \mathrm{~kg}$ per each sandy soil of pH 7.8 and E.C. $1.1 \mathrm{dsm}^{-1}$. The soil in each pot was artificially contaminated with concentrations of lead chloride $\left(\mathrm{PbCl}_{2}\right)$ by $0.5,1$, and $5 \%$ according to the proposed treatments. Three pre-germinated faba bean seeds were cultivated in each pot and immediately inoculated with the bioremediating bacteria or each heavy metal concentration where each pot received $30 \mathrm{ml}$ inoculum of the bacteria and irrigated with tap water to the field capacity (without excess water leaking outside the pot), each treatment was triplicated. During the experiment, irrigation was carried out according to the plant needs with half-strength solutions, where both compounds $\mathrm{Ca}\left(\mathrm{NO}_{3}\right)_{2} \cdot 4 \mathrm{H}_{2} \mathrm{O}$ and $\mathrm{NH}_{4} \mathrm{NO}_{3}$ were eliminated, Hoagland nutrient solution (Hoagland and Arnon, 1950) and tap water interchangeably. As a leguminous plant, the whole treatments of faba bean were inoculated with a liquid culture of Rhizobium leguminosarum previously isolated from faba bean root nodules. The following 7 treatments were applied: control, 
$0.5 \%(2000 \mathrm{mg} / \mathrm{L}) \quad \mathrm{Pb}, 0.5 \%(2000 \mathrm{mg} / \mathrm{L}) \mathrm{Pb}+\mathrm{Pb}-$ remediating bacterium, $1.00 \%(2500 \mathrm{mg} / \mathrm{L}) \mathrm{Pb}$, $1.00 \%(2500 \mathrm{mg} / \mathrm{L}) \mathrm{Pb}+$ Pb-remediating bacterium, $5.00 \%(3000 \mathrm{mg} / \mathrm{L})$

$\mathrm{Pb}$, $5.00 \%(3000 \mathrm{mg} / \mathrm{L}) \mathrm{Pb}+$ Pb-remediating bacterium.

\subsection{Growth parameters determination}

At the flowering stage, the faba bean plants were carefully uprooted and washed several times to remove the soil detritus. The plants were put to dry and the following parameters were estimated, plant fresh weight, plant height $(\mathrm{cm})$, plant dry weight (gm/plant). The plants were oven-dried at $75^{\circ} \mathrm{C}$ for $48 \mathrm{hr}$. to constant dry weight.

\section{Determination of mineral elements}

The determination of mineral elements of each treatment was performed according to Humphries (1956) method. The fine powder of plant $0.25 \mathrm{gm}$ was placed in digestion tube with $1 \mathrm{ml}$ of concentrated $\mathrm{H}_{2} \mathrm{SO}_{4}$ and placed on a sand heater inside the hood for 15-20 minutes till it became dark in color then left to cool and $1 \mathrm{ml}$ of a mixture of perchloric acid and concentrated $\mathrm{H}_{2} \mathrm{SO}_{4}$ was added and heated again for 30-50 minutes until the sample's color became transparent as water. The tubes were lifted out and distilled water was added up to $100 \mathrm{ml}$. The nutrient elements $\mathrm{N}, \mathrm{P}, \mathrm{K}$, and $\mathrm{Pb}$ were determined using spectrophotometer-ICPDES-Oplmia 8000.

\section{Statistical Analysis}

The obtained results were statistically analyzed using the computer program SPSS 17(2007). ANOVA test (one way) was applied to differentiate between the various means of treatments. The experimental design was a complete randomized block design. Differences among means were compared using the least significant difference $(\mathrm{LSD})$ at $\mathrm{p}<0.05$.

\section{RESULTS}

Bio-remediation of faba bean by a $\mathrm{Pb}$-tolerant bacteria:

A - Influence of inoculation of faba bean plants by the bacteria Bacillus amyloliquefacienss on the plant growth parameters:

Regarding studying the bio-remediating efficiency of the bacteria Bacillus amyloliquefacienss on faba bean plant growth parameters and nutrient content, the results are presented in (table1).

Concerning faba bean plant height inoculation of faba bean plants with $B$. amyloliquefacienss increased plant height under $\mathrm{Pb}$ concentrations $0.5 \%$ and $1.0 \%$ without a significant difference at $0.5 \%$ but with a significant difference at $1.0 \% \mathrm{~Pb}$ concentration giving 55.83 and $55.66 \mathrm{~cm}$ in comparison with the same non-inoculated plants at $0.5 \%$ and $1.0 \% \mathrm{~Pb}$ concentration with 52.83 and $37.00 \mathrm{~cm}$, but at $5 \% \mathrm{PbCl}_{2}$ concentration the noninoculated treatment significantly exceeded the inoculated treatment giving the highest plant height $32.00 \mathrm{~cm}$ compared to $16.00 \mathrm{~cm}$. It is worthy to mention that the control treatment-induced plant height reached $60 \mathrm{~cm}$ which is higher than all other treatments. Also for the plant fresh weight the inoculated faba bean plants gave the highest plant fresh weight at $0.5 \%$ and $1.0 \% \mathrm{~Pb}$ concentrations compared to the non-inoculated plants with no significant difference at $0.5 \% \mathrm{~Pb}$ concentration but with a significant difference at $1.0 \%$ reaching 36.63 (41.1\%increase) and 34.33 (250.3\% increase) $\mathrm{gm} /$ plant under inoculated plants compared to 25.96 and $9.80 \mathrm{gm} /$ plant under non-inoculated plants.

At $5 \% \mathrm{PbCl}_{2}$ concentration the non-inoculated plants dominated the inoculated plants giving the highest plant fresh weight $13.4 \mathrm{gm} /$ plant compared to $3.4 \mathrm{gm} /$ plant by the inoculated plants without significant difference between them. The bio- 
remediated treatments with $B$. amyloliquefacienss produced faba bean fresh weight comparable to that obtained with the control treatment without significant variations at 0.5 and $1 \% \quad \mathrm{PbCl}_{2}$ concentrations.

The bacteria inoculated plants produced significantly high dry weight reached 8.78 and 6.56 $\mathrm{g} /$ plant against 2.60 and $1.54 \mathrm{~g} / \mathrm{plant}$ at 0.5 and $1 \%$ $\mathrm{PbCl}_{2}$ concentrations by non-inoculated plants respectively. But at $5 \% \mathrm{PbCl}_{2}$ concentration the non-inoculated faba bean plants produced a higher dry weight compared to the inoculated plants without significant differences between them. Furthermore, the bio-treated plants of faba bean produced dry weight with no significant variations with the control treatment at 0.5 and $1 \% \mathrm{PbCl}_{2}$ concentration.

Table (1): Bioremediation influence of B. amyloliquefaciens on some growth parameters of Faba bean plants

\begin{tabular}{|c|c|c|c|c|}
\hline \multicolumn{2}{|c|}{ Parameters } & $\begin{array}{c}\text { Plant height } \\
(\mathbf{c m})\end{array}$ & $\begin{array}{l}\text { Fresh weight } \\
\text { (g/plant) }\end{array}$ & $\begin{array}{l}\text { Dry weight } \\
\text { (g/plant) }\end{array}$ \\
\hline \multirow{4}{*}{ Lead concentration $(\%)$} & Control & $60.00 \mathrm{a}$ & $38.93 a$ & $10.046 \mathrm{a}$ \\
\hline & 0.5 & $52.83 \mathrm{a}$ & $25.96 \mathrm{ab}$ & $2.603 \mathrm{bc}$ \\
\hline & 1.0 & $37.00 \mathrm{~b}$ & $9.80 \mathrm{c}$ & $1.540 \mathrm{c}$ \\
\hline & 5.0 & $32.00 \mathrm{~b}$ & $13.40 \mathrm{bc}$ & $2.780 \mathrm{bc}$ \\
\hline \multirow{3}{*}{$\begin{array}{l}\text { Lead concentration (\%) } \\
+ \text { B. amyloliquefaciens }\end{array}$} & 0.5 & $55.83 \mathrm{a}$ & $36.63 \mathrm{a}$ & $8.783 a$ \\
\hline & 1.0 & $55.66 \mathrm{a}$ & $34.33 \mathrm{a}$ & $6.560 \mathrm{ab}$ \\
\hline & 5.0 & $16.00 \mathrm{c}$ & $3.50 \mathrm{c}$ & $0.380 \mathrm{c}$ \\
\hline \multicolumn{2}{|l|}{ LSD } & 9.32 & 14.41 & 4.83 \\
\hline
\end{tabular}

Values of the same letters are not statistically significant; values are the means of three replicates.

B - Effect of B. amyloliquefaciens inoculation on faba bean plant content of nutrients: 1 - N- content:

The impact of various lead concentrations either alone or in combination with the bio-remediator Bacillus amyloliquefaciens on the macro-nutrients $(\mathrm{N}, \mathrm{P}$, and $\mathrm{K})$ in addition to $\mathrm{Pb}$-content in faba bean plants is shown in Table (2).

Regarding the N-content of faba bean plants, the results reveal that the non-inoculated plants gave significantly the highest $\mathrm{N}$-content at $\mathrm{Pb}$ concentrations $0.5 \%$ and $1.0 \%$ giving 20.57 and $21.95 \mathrm{mg} / \mathrm{g} \mathrm{N}$ dry weight respectively compared to the inoculated plants with 11.62 and $13.11 \mathrm{mg} / \mathrm{g} \mathrm{N}$ dry weight respectively. No significant variations were recorded between the plant $\mathrm{N}$ content under the B.amyloliquefaciens inoculated plants and the non-inoculated faba bean plants treated with $5 \%$ $\mathrm{PbCl}_{2}$ concentration as the results were 21.95 and $21.98 \mathrm{mg} / \mathrm{g}$ dry weight respectively. Plant Nitrogen content under inoculation at lead concentrations 0.5 and $1 \%$ induced $\mathrm{N}$-content comparable to that obtained with the control treatments with no significant differences.

2 - P-content 
As for the P-content of faba bean plants, the results (Table 2) indicate that P-content in the plants inoculated with $B$. amyloliquefaciens ranged between 0.12 and $2.24 \mathrm{mg} / \mathrm{g}$ dry weight, the highest significant value was found with the treatment of $5 \% \quad \mathrm{PbCl}_{2}$ (2.24 mg/g dry weight). The noninoculated plants gave significantly the highest $\mathrm{P}$ content at $\mathrm{Pb}$ concentrations $0.5 \%$ and $1.0 \%$ giving 0.37 and $0.55 \mathrm{mg} / \mathrm{g} \mathrm{P}$ dry weight respectively compared to the inoculated plants with 0.13 and $0.23 \mathrm{mg} / \mathrm{g} \mathrm{P}$ dry weight respectively. While the B.amyloliquefaciens inoculated plants significantly dominated the non-inoculated faba bean recording the highest $\mathrm{P}$ content 2.24 compared to $0.35 \mathrm{mg} / \mathrm{g} \mathrm{P}$ dry weight under treatment with $5 \% \quad \mathrm{PbCl}_{2}$ concentration. Faba bean plant $\mathrm{P}$ content under inoculation at lead concentrations 0.5 and $1 \%$ induced P-content comparable to that obtained with the control treatments with no significant differences between them.

\section{3 - K-content}

Regarding faba bean plants content of potassium $(\mathrm{K})$, the results (Table 2) indicate that K-content in the plants inoculated with $B$. amyloliquefaciens ranged between 1.72 and $15.32 \mathrm{mg} / \mathrm{g}$ dry weight, the highest significant value was found with the treatment of $5 \% \mathrm{PbCl}_{2}(15.32 \mathrm{mg} / \mathrm{g}$ dry weight $)$. The non-inoculated plants gave significantly the highest $\mathrm{K}$-content at $\mathrm{Pb}$ concentrations $0.5 \%$ and $1.0 \%$ giving 18.17 and $14.11 \mathrm{mg} / \mathrm{g} \mathrm{K}$ dry weight respectively compared to the $B$. amyloliquefaciens inoculated plants with 10.55 and $1.72 \mathrm{mg} / \mathrm{g} \mathrm{K}$ dry weight respectively. But the B.amyloliquefaciens inoculated plants significantly dominated the noninoculated faba bean recording the highest $\mathrm{K}$ content 15.32 compared to $12.58 \mathrm{mg} / \mathrm{g}$ K dry weight under treatment with $5 \% \mathrm{PbCl}_{2}$ concentration.

\section{4 - Pb-content}

The $\mathrm{Pb}$-content of faba bean plants ranged between 0.5 under the control and $11.0 \mathrm{ppm}$, under $5 \% \mathrm{PbCl}_{2}$ concentration. No significant differences between faba bean plant $\mathrm{Pb}$ content under non-inoculation and inoculation with the bacteria B.amyloliquefaciens $\mathrm{Pb}$ concentration of $0.5 \%$ and $5 \%$ where the results were significantly 1.6 and 11.0 ppm under non-inoculation and 1.0 and 10.0 ppm under inoculation with the bacteria respectively. But at a $\mathrm{Pb}$ concentration of $1.0 \%$ the bacterial inoculated plants dominated giving significantly the highest faba bean plant $\mathrm{Pb}$ content $4.0 \mathrm{ppm}$ compared to the non-inoculated faba bean plants with only $2.2 \mathrm{ppm}$.

Table 2: Faba bean plants content of $\mathrm{N}, \mathrm{P}, \mathrm{K}$, and $\mathrm{Pb}$ as affected by $\mathrm{B}$. amyloliquefaciens inoculation at different $\mathrm{Pb}$ concentrations

\begin{tabular}{|c|c|c|c|c|c|}
\hline \multicolumn{2}{|c|}{ Parameters } & $\begin{array}{c}\text { N-content } \\
\text { Treatments }\end{array}$ & $\begin{array}{c}\text { P-content } \\
(\mathbf{m g} / \mathbf{g})\end{array}$ & $\begin{array}{c}\text { K-content } \\
(\mathbf{m g} / \mathbf{g})\end{array}$ & $\begin{array}{c}\text { Pb-content } \\
(\mathbf{p p m})\end{array}$ \\
\hline \multirow{3}{*}{ Lead concentration (\%) } & Control & $13.67 \mathrm{~b}$ & $0.12 \mathrm{~d}$ & $6.73 \mathrm{~d}$ & $0.5 \mathrm{e}$ \\
\cline { 2 - 6 } & $\mathbf{0 . 5}$ & $20.57 \mathrm{a}$ & $0.37 \mathrm{c}$ & $18.17 \mathrm{a}$ & $1.6 \mathrm{~d}$ \\
\cline { 2 - 6 } & $\mathbf{1 . 0}$ & $21.95 \mathrm{a}$ & $0.55 \mathrm{~b}$ & $14.11 \mathrm{~b}$ & $2.2 \mathrm{~d}$ \\
\cline { 2 - 6 } & $\mathbf{5 . 0}$ & $22.19 \mathrm{a}$ & $0.35 \mathrm{c}$ & $12.58 \mathrm{bc}$ & $11.00 \mathrm{a}$ \\
\hline \multirow{2}{*}{$\begin{array}{c}\text { Lead concentration }(\%) \\
\text { + B. amyloliquefaciens }\end{array}$} & $\mathbf{0 . 5}$ & $11.62 \mathrm{~b}$ & $0.13 \mathrm{~d}$ & $10.55 \mathrm{c}$ & $1.0 \mathrm{~d}$ \\
\cline { 2 - 6 } & $\mathbf{1 . 0}$ & $13.11 \mathrm{~b}$ & $0.23 \mathrm{~cd}$ & $1.72 \mathrm{bc}$ & $4.0 \mathrm{c}$ \\
\hline & $\mathbf{5 . 0}$ & $21.98 \mathrm{a}$ & $2.24 \mathrm{a}$ & $15.32 \mathrm{ab}$ & $10.0 \mathrm{~b}$ \\
\hline LSD & & $\mathbf{2 . 8 6}$ & $\mathbf{0 . 1 9}$ & $\mathbf{3 . 4 9}$ & $\mathbf{0 . 9}$ \\
\hline
\end{tabular}

Values of the same letters are not statistically significant; values are the means of three replicates. 


\section{DISCUSSION}

Bio fertilization of faba bean with $\mathrm{Pb}$ remediation bacteria

Faba bean plants when inoculated with Bacillusamyloliquefaciens and planted in $\mathrm{Pb}$ polluted soil have shown a significant increase in plant height, plant fresh weight, and plant dry weight compared to those planted without bacterial inoculation, especially under $\mathrm{Pb}$ concentration $0.5 \%$ and $1.0 \%$. These findings are in agreement with many other results found by other researchers. $\mathrm{Wu}$ et al. (2006) found the inoculation of Azotobacter chroococcum stimulated the growth of Brassica juncea under $\mathrm{Pb}$ concentration. Gomaa et al. (2012) stated that the application of Azospirillum and Rhizobium in the presence of $300 \mathrm{ppm} \mathrm{Pb}$ induced a highly significant increase in wheat shoot dry weight over the positive control.

Jing et al. (2013) found that inoculation of rapes with bacterial strain Enterobacter sp. (JYX7) and Klebsiella sp. (JYX10) had significantly higher dry weights compared to those without inoculation grown in soils amended with $\mathrm{Pb}(200 \mathrm{mg} / \mathrm{kg})$. Ahmed and Khan, (2012) found that in the soil amended with $\mathrm{Pb}$, the Rhizobium strain RL9 isolated from the nodules of lentil grown in metal contaminated soil, significantly increased growth and nodulation of lentil compared to plants grown in absence of this Rhizobium strain.

But the $\mathrm{Pb}$ contaminated soil without bacterial inoculation dominated those with inoculated bacteria only under $5 \% \mathrm{~Pb}$ concentration given the highest plant height, fresh and dry weight. This may be attributed to the fact that the inoculated bacteria itself was affected by the accumulation of high $\mathrm{Pb}$ concentration, thus resulting in unavailability of nutrient to the plant and thus causing retardation in the growth parameters of Faba bean (height, fresh, dry weight) as was reported by (Henry 2000) that oxyhydroxides, organic, carbonate, and precipitated forms of lead are the most strongly bound to the soil. The capacity of the soil to adsorb lead increases with increasing $\mathrm{pH}$, cation exchange capacity (CEC), organic carbon content, soil/water Eh (redox potential), and phosphate levels.

Mangkoediharjo and Surahmaida (2008) planted Jatropha curcas phytoremediation in pots for 30 days in the soil polluted with different $\mathrm{Pb}$ concentrations and found that beyond $50 \mathrm{mg} / \mathrm{kg}$ soil $\mathrm{Pb}$ was more toxic to plants. Gupta et al. (2012) mentioned that heavy metals generally when present in soil show

Role of the rhizophore bacterium $B$. amyloliquefaciens in faba bean content $\mathrm{N}, \mathrm{P}, \mathrm{K}$, and Pb: Inoculation of faba bean plants with $B$. amyloliquefaciens significantly increased the plant content of nutrients $\mathrm{N}, \mathrm{P}, \mathrm{K}$, and $\mathrm{Pb}$ at $\mathrm{Pb}$ concentration of $5.0 \%$ concentration compared to the control. On the other hand, the non-inoculated faba bean plants contained significantly higher N, P, and $\mathrm{K}$ at the $\mathrm{Pb}$ concentration of $0.5 \%$ and $1.0 \%$ compared to the bacteria inoculated plants, but at $5.0 \% \mathrm{~Pb}$ concentration the $B$. amyloliquefaciens inoculated plants gave significantly the highest $\mathrm{N}$, $\mathrm{P}, \mathrm{K}$, and $\mathrm{Pb}$ content compared to the noninoculated plants. It seems that when $\mathrm{Pb}$ concentration increases up to $5.0 \%$ the inoculated plants absorb more N, P, K and $\mathrm{Pb}$ compared to noninoculated plants. This finding agrees with the results obtained by many other researchers. Panwichian et al. (2010) inoculated two metalresistant bacteria Rhodobiummarinum (NW16) andRhodobactersphaeroides (KM524) with 62.63 $\mathrm{mg} / \mathrm{kg}$ dry weight $\mathrm{Pb}$, and they were able to reduce the level of $\mathrm{Pb}$ in the soil by $39 \%$. 
Muneer (2005) isolated $8 \mathrm{~Pb}$-resistant bacteria from industrial wastewater, and they showed maximum resistance against $\mathrm{Pb}^{+2}(2.9 \mathrm{mg} / \mathrm{L})$ and removed 65 $82 \%$ of the $\mathrm{Pb}$ from the medium after 72 hours of the inoculation. Jing et al. (2013) inoculated Rape with bacterial strains Enterobacter sp. (JYX7) and Klebsiella sp. (JYX10) and got significant concentrations and uptake of $\mathrm{Pb}$ by plants both in roots and shoots compared to those without inoculation growth in soils amended with $\mathrm{Pb}$ (200 $\mathrm{mg} / \mathrm{kg}$ ).

The results of the contents of the nutrients, N, P, K in Faba bean plants with the different $\mathrm{Pb}$ concentrations showed that the plants inoculated with the bacteria B. amyloliquefaciens attained the highest $\mathrm{N}, \mathrm{P}$, and $\mathrm{K}$ plant content when planted under $\mathrm{Pb}$ concentration of $5.0 \% \mathrm{~Pb} \mathrm{Cl}_{2}$ compared to both other treatments, control and without bacterial inoculation. Work by other researchers may augment these results obtained in this study. Mamaril et al. (1997) mentioned that the bacteria can protect the plant against the toxic effects of the $\mathrm{Pb}$ through adsorption/desorption mechanisms and Ahmed and Khan (2012) found that in a soil amended with Cr iii, the Rhizobium strain RL9 isolated from $\mathrm{Pb}$, the contaminated soil, significantly increased nodulation of the lentil plants due mostly to increase of the nutrient uptake compared to those plant grown in the absence of this Rhizobium strain.

As for the effects of bio-remediation using the bacteria $B$. amyloliquefaciens in sequestering of $\mathrm{Pb}$ from soil contaminated with $\mathrm{Pb}$, the results of this study showed that at $1.0 \%$ of lead concentration, in faba bean inoculated with bacteria, there is a high degree of tendency to accumulate and concentrate lead more than those treated with lead alone. This may be attributed to that at high $\mathrm{Pb}$ concentrations in the soil the associates faba bean shoot itself might be affected.

On the other hand, at the highest concentration of lead $5 \%$, the fraction of lead absorbed from contaminated soil by faba bean-free from remediating bacteria has no significant difference from that absorbed by faba bean remediated by bacteria, and this can be postulated as reported by Meagher (2000) that not all contaminants are easily treated by bioremediation using microorganisms, like $\mathrm{Pb}$ and $\mathrm{Cd}$ are not easily absorbed or captured by microorganisms.

Yadav et al. (2012) observed that the absorption capacity of Bacillus subtilis for $\mathrm{Cd}$ increases by increasing initial metals concentration, while there's some kind of changeable for sorption of $(\mathrm{Pb})$ with the increasing of metal ion concentration, at the different initial concentration of the lead solution, it was slow when the concentration of lead increased from 5 to $10 \mathrm{mg}$. $1^{-1}$, but it increased lead absorption via Bacillus subtilis with concentration $25 \mathrm{mg} / \mathrm{l}$ and then reduced with concentration $50 \mathrm{mg} / \mathrm{l}$. The differences between these two results of removing ions by the same bacterium may be attributed to an alteration in a capability of the active site suitable for both metal ions on the surface of the cell and this agrees with the finding of this study that the highest $\mathrm{Pb}$ absorbed by the plants was with the concentration $1.0 \%$ and not with the highest concentration $5.0 \%$.

\section{CONCLUSION}

The bacteria strain Bacillus amyloliquefaciens subsp. plantarum UCMB 5033 was found good bioremediator of Faba bean plants growing under lead $(\mathrm{Pb})$ contaminated soil up to $2500 \mathrm{mg} / \mathrm{L} 1.0 \% \mathrm{mg} / \mathrm{L}$ $5 \%$. Growth parameters (plant height, plant fresh weight, and plant dry weight) of the bacteria inoculated Faba bean plants were significantly 
higher compared to the non-inoculated Faba bean plants under $\mathrm{Pb}$ concentration of $0.5 \%$ and $1.0 \%$ Regarding the plant nutrient NPK contents the noninoculated plants gave significantly higher contents compared to the bio-remediated plants at the $\mathrm{Pb}$ concentrations of 0.5 and $1.0 \%$, but the bioremediated plants dominated the non-inoculated faba bean plants in absorbing the highest $\mathrm{Pb}$ especially under $1.0 \% \mathrm{~Pb}$ concentration. Bacillus amyloliquefaciens subsp. plantarum UCMB 5033 may be considered a bio-remediator for Faba bean plants grown under $\mathrm{Pb}$ contaminated soils.

\section{ACKNOWLEDGEMENT}

My thanks are to my department colleagues and technicians for their continuous support, encouragement and providing me with all the required facilities to achieve the practical work of the thesis, and also to my family for their constant support

\section{REFERENCES}

Ahemad, M. and Khan, M.S. 2012. Effect of fungicides on plant growth promoting activities of phosphate solubilizing Pseudomonas putida isolated from mustard (Brassica compestris) rhizosphere. Chemosphere, 86, pp. 945-950.

Chen C. and Wang, J. (2007). Response of Saccharomyces cerevistae to lead ion stress. Appl. Microbiol Biotechnol 74, 683687.

Gomaa, A. M., Al-fassi, F. A., Al-kenawy, Z. and Al-Gharbawi, H.T. 2012. Role of Azospirillum and Rhizobium in BioRemediating $\mathrm{Cd}$ and $\mathrm{Zn}$ Polluted Soil Cultivated with Wheat Plant. Australian Journal of Basic and Applied Sciences, 6(10): 550-556.
Gupta, K., Chatterjee, C., and Gupta, B. 2012. Isolation and characterization of heavy metal tolerant Gram positive bacteria with bioremedial properties from municipal waste rich soil of Kestopur Canal (Kolkata), West Bengal, India. Biologia 67(5):827836.

Henry, J.R. 2000. An Overview of the Phytoremediation of Lead and Mercury. U.S. Environmental Protection Agency Office of Solid Waste and Emergency Response Technology Innovation office Washington, D.C.

Hoagland, D.R. and D.I. Arnon, 1950. The waterculture method for growing plants without soil. California Agric. Exp. Station Circ., 347: 1-32.

Humphries, E. C. 1956. Mineral components and ash analysis. In: PEACH K. \& TRACEY M. V. (eds.), Modern Methods of Plant Analysis I, pp. 468-502. - Springer Verlag, Berlin-Göttingen-Heidelberg.

Jing, Y.X., Yan J.L., He H. D., Yang D.J., Xiao L., Zhong T., Yuan M., Cai, X.D. and Li, S.B. 2013. Characterization of bacteria in the rhizosphere soils of Polygonum pubescens and their potential in promoting growth and $\mathrm{Cd}, \mathrm{Pb}, \mathrm{Zn}$ uptake by Brassica napus. International Journal of Phytoremediation, Vol. 161, Iss. 4: pp.321-333.

Mangkoedihardjo, S. and Surahmaida. 2008. Jatropha curcas L. for Phytoremediation of Lead and Cadmium Polluted Soil. World Applied Sciences Journal, Vol. 4 (4): pp. 519-522.

Mamaril J.C., Paner E.T. and Alpante B.M. 1997. Biosorption and desorption studies of chromium (iii) by free and immobilized 
Rhizobium (BJVr 12) cell biomass, Sun,F. and Shao(2007). Biosorption and Biodegradation. 8, 275-285.

bioaccumulation of $\mathrm{Pb}$ by Benicillium spp. Psf-2 isolated from the deep sea sediment of the Pacific Ocean. Extremophilies 11, elemental and organic pollutants. Curr. Opin. Plant Biol. 3:153-162. 853-858.

Muneer, B. 2005. Role of microorganism in remediation of heavy metals in the wastewaters of tanneries. Ph. D. Thesis, Higher Education Commission, Pakistan, University of the Punjab, Lahore.

Murthy, S., Bali G. and Sarangi, S.(2012). Lead biosorption by bacterium isolated from industrial effluents. International J. of Microbiology Res., vol.4, issue 3: pp. 192196.

Panwichian, S., Kantachote, D., Wittayaweerasak, B. and Mallavarapu M. 2010. Isolation of purple nonsulfur bacteria for the removal of heavy metals and sodium from contaminated shrip ponds. Environmental Biotechnology. 13(4): 12 pp. DOI: 10.2225/vol13-issue4-fulltext-8.

Rathnayake, I.V.N., Medharaj, M., Bolan, N. and Naidu, R. 2010. Tolerance of heavy metals by gram positive soil bacteria. IJCEEIJENS, 53 (2009), pp. 1185-1189.

Sheng, X.F. and Xia, J.J. 2008. Improvement of rape (Brassica napus) plant growth and cadmium uptake by cadmium-resistant bacteria. Chemosphere, 64, pp. 1036-1042.

Wu, C.H., Wood, T.K., Mulchandani, A., and Chen, W. 2006. Engineering plant-microbe symbiosis for rhizoremediation of heavy metals. Appl. Environ. Microbiol., 72, pp. 1129-1134.

Yadav, H., Satish, N., Bhanu, M. and Maradala, P. 2012. Studies on biological removal of plumb $(\mathrm{Pb})$ by Bacillus subtilis. International J. of Scientific and Engineering Research, 3(7): PP.336-339.

Zanardini, E., Andreoni, V., Borina, S., Cappitellia, F., Daffonchio,D., Talottaa, P., Sorlinia, C., Ranallib, G., Brunic, S. \& Cariatic,F. (1997). Lead-resistant microorganisms from red stains of marble of e Certosa of Pavia, Italy an d use of nucleic acid-based techniques for their detection. Int Biodeter Biodegr 40, 171-182

Zanardini, E. Anderioni, U. Borina, S., Cappitellia, F. (1997). Lead resistance microorganisms from red stains of marble of Certosa of Pavica , Italy and use of nucleic acid -based techniques for their detections. Int.Biodeter Bioderg 40,171-182. 